\title{
The Impact of Urban Flooding on Surface Water Quality of Awka Town
}

\author{
Anthony C. Okoye ${ }^{1}$, Emma E. Ezenwaji ${ }^{2}$, Kabir A. Awopeju ${ }^{3}$ \\ ${ }^{1}$ Department of Environmental Management, Nnamdi Azikiwe University, Awka, Nigeria; ${ }^{2}$ Department of Geography and Meteor- \\ ology, Nnamdi Azikiwe University, Awka, Nigeria; ${ }^{3}$ Department of Statistics, Nnamdi Azikiwe University, Awka, Nigeria. \\ Email: emmaezenwaji@gmail.com
}

Received May 31 ${ }^{\text {st }}, 2013$; revised June 29 2 th 2013 ; accepted July $23^{\text {rd }}, 2013$

Copyright (c) 2014 Anthony C. Okoye et al. This is an open access article distributed under the Creative Commons Attribution License, which permits unrestricted use, distribution, and reproduction in any medium, provided the original work is properly cited. In accordance of the Creative Commons Attribution License all Copyrights (C) 2014 are reserved for SCIRP and the owner of the intellectual property Anthony C. Okoye et al. All Copyright (C) 2014 are guarded by law and by SCIRP as a guardian.

\section{ABSTRACT}

Some physico-chemical and bacteriological parameters were analyzed for in the water samples of four different ponds located in Awka town both prior and after the rain to ascertain the impact of flood in these ponds and to establish whether the pollution was significant. Four samples were collected from each pond both before the rain and after making it a total of thirty-two samples. Twenty-seven parameters were analyzed for in each of the samples. The result revealed that twelve parameters exceeded WHO standard before the rain while fourteen exceeded after the rain. There was significant increment in the values of the analyzed parameters after the rain when compared with the value before the rain as revealed by the Anova statistical tool. It was discovered that there was a major increase in the bacteriological parameters after the rain which implied the serious health impact. It was recommended that users who utilized these ponds for squeezing bitter leaf, processing cassava and washing meats etc. should do so with the caution so as not to expose people to health problems.

\section{KEYWORDS}

\section{Ponds; Flood; Pollution; Health Impact; WHO Standard}

\section{Introduction}

Flooding is a localized hazard that generally results from anthropogenic activities and moderately to large clirnatologic events such as the intense rainfall. It is one of the most wide spread climatic hazards that poses multiple risks to human health [1]. Urban areas especially those in developing countries experience various types of disasters in most periods of the rainy season as a result of flooding. Urbanization aggravates flooding by restricting where flood waters can go, covering large parts of the ground with roofs, roads and pavements, obstructing sections of natural channels and building drains that ensure that water moves to rivers faster than it does under natural conditions. As more and more people crowd into cities, the effects intensify. As a result, quite moderate storms produce high flows in rivers because there are more hard surfaces and drains.

Most studies in urban flooding have concentrated at- tention in describing the nature of urban floods, listing the causes of such floods and their destructive consequences on life and property [2]. The destructive effects of floods in urban areas have been widely recognized in Nigeria [3-5]. The causes of such urban flooding has been linked to climatic factors such as rainfall [6], topography [7], urban sprawl [8], poor urban planning [9] and other environmental factors [10]. Flooding is one of the major causes of the surface water pollution. Flood washes down all sorts of liquid and solid pollutants from the city and deposits them into the surface water bodies. People make use of these water bodies to process cassava, squeeze bitter leaf and do other things that could expose humans to health hazards. Most studies in the urban flooding deal mainly with the nature and causes of the floods and their general destructive consequences. There is a need to assess the quality of these ponds and to investigate the extent of the pollution so as to ascertain the status of the ponds. This is what this study seeks to address. 


\section{Materials and Methods}

\subsection{Study Area}

Awka town is located between Latitude $6.24^{\circ} \mathrm{N}$ and $6.28^{\circ} \mathrm{N}$ and Longitudes $7.00^{\circ} \mathrm{F}$ and $7.06^{\circ} \mathrm{F}$ on the Southeastern part of Nigeria (Figure 1). The study area covers 144.5 hectares with a 2006 contested population of 116,208 persons [11]. This includes such outlying communities as Amawbia, Okpuno and Amansea which are fastiy being annexed to the town by urbanization. The town's topography presents a rugged relief as it lies completely on Awka-Or1u upland. Generally, the average height of the town range from $91 \mathrm{~m}$ in the western parts of the town to $160.2 \mathrm{M}$ in the eastern zone, although there are local variations within the town which are drained by a number of streams. The climate is the tropical wet and. dry type according to Koppen's classification system with a clear cycle of season. The mean daily maximum temperature is usually $27^{\circ} \mathrm{C}$ all over the year. This could reach $34^{\circ} \mathrm{C}$ in March, and. lowest during the hamartan months of December and January. The mean annual rainfall according to the local meteorological station reveals a mean rainfall of about $1600 \mathrm{~mm}$ with a relative humidity of $80 \%$ at dawn.

\subsection{Site Selection and Sample Collection}

This study was carried out during the rainy season of 2010. Samples were collected in May and September. Four ponds were selected for this study as they are the only ones available in Awka town. Pond 1 is located at the back of Bishop Crowther seminary Aka Pond two is along Obinagu road near Ejiofor bread Industry Pond 3 is opposite Katta market while pond 4 is behind Crescent Sprig Hotel Iyiagu (see Figure 1) Four samples were collected from each of the ponds using sterile $500 \mathrm{ml}$ glass sample bottles, with caps at different points before the rain event and immediately after the rain event. Another batch of samples were collected in September making a total of thirty two samples for the four ponds. The samples were stored at about $4{ }^{\circ} \mathrm{C}$ in a refrigerator prior to the analysis.

\subsection{Sample Analysis}

\subsubsection{Physico-Chemical Analysis}

The temperature of the samples were measured with la-

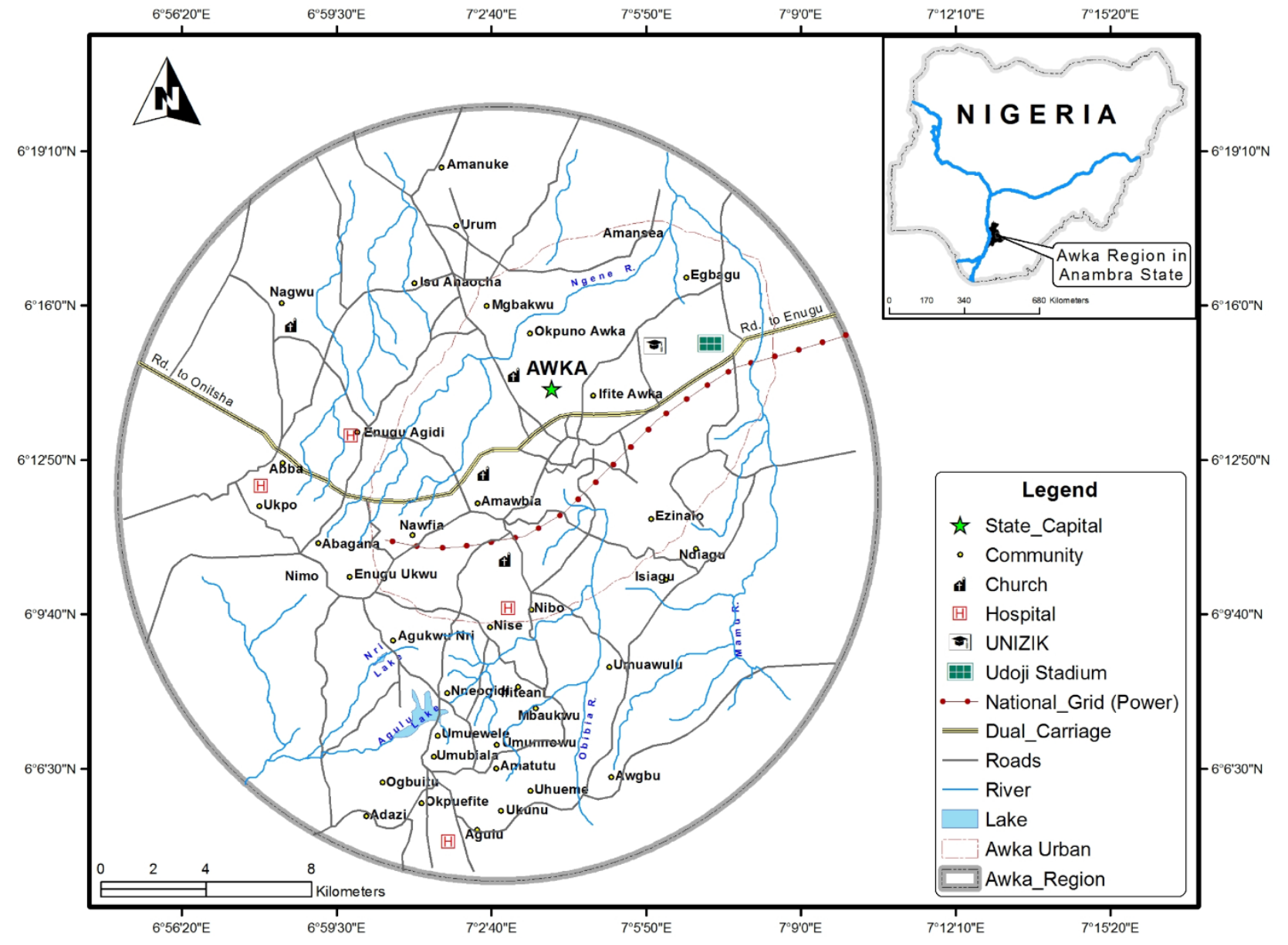


Figure 1. Map of Awka urban area, Nigeria.

boratory mercury bulb thermometers calibrated in degree centigrade. The colours were determined using the Pt-Co method (Mamta, 1999). The $\mathrm{pH}$ of the samples were determined using a pH meter (Model WTW Weiheim 88 68594) while the turbidity was determined by the formazine Attenuation method [12]. Total hardness was determined by the EDTA titrating procedure. Total dissolved solids (TDS) of samples were determined gravimetrically after the samples were over dried to constant weight at $105^{\circ} \mathrm{C}$. Nitrates were determined through the colorimetric diazotization method and the phosphates by persulfate UV oxidation method [13]. The carbonates and bicarbonates were determined by titrating $50 \mathrm{~m} 1$ of the samples with $0.25 \mathrm{M}$ solution of the tetraoxosulphate (vi) acid using phenolphthalein and methyl orange as indicators. The chloride content was determined by the Mohrs method [14]. The elements were determined using Unicam SP 1700 Atomic Absorption Spectrophotometer.

\subsubsection{Microbiological Analysis}

The membrane filtration method (MF) was used to enumerate total coliforms and faecal coliform counts of the water samples [15], while pour plate was used to determine the heterotrophic count.

\subsubsection{Statistical Analysis}

Analysis of Variance (ANOVA) statistical technique was the tool applied in the analysis of the data generated. The $\mathrm{H}_{0}$ reads that there are significant differences between the observed parameters after the rainfall while $\mathrm{H}_{1}$ reads that there are no significant differences between the observed parameters after the rain.

\section{Result and Discussion}

The result of the physico-chemical and bacteriological parameters of the samples are presented in Table 1 . The

Table 1. Physico-chemical and bacterological analyses of samples.

\begin{tabular}{|c|c|c|c|c|c|c|c|c|}
\hline \multirow{2}{*}{ Parameters } & \multicolumn{4}{|c|}{ Before Rainfall } & \multicolumn{4}{|c|}{ After Rainfall } \\
\hline & Pond 1 & Pond 2 & Pond 3 & Pond 4 & Pond 1 & Pond 2 & Pond 3 & Pond 4 \\
\hline Appearance & muddy & Slightly clear & Slightly clear & muddy & muddy & cloudy & cloudy & muddy \\
\hline Temperature $\left({ }^{\circ} \mathrm{C}\right)$ & 26 & 25 & 25 & 26 & 29 & 27 & 29 & 26 \\
\hline Colour (Ap-co) & 120 & 110 & 115 & 120 & 200 & 150 & 180 & 190 \\
\hline Odour & 8.6 & 7.4 & 8.1 & 6.9 & 8.7 & 8.8 & 8.6 & 7.4 \\
\hline $\mathrm{PH}$ & 688 & 649 & 520 & 593 & 1286 & 1249 & 820 & 1130 \\
\hline Conductivity ( $\mu \mathrm{ohms} / \mathrm{cm})$ & 510 & 500 & 500 & 721 & 910 & 840 & 860 & 940 \\
\hline TDS (mg/l) & 2 & 2 & 2 & 4 & 4 & 3 & 4 & 5 \\
\hline BOD (mg/l) & & & & & & & 22 & 18 \\
\hline Sality (mg/l) & 24 & 33 & 35 & 32 & 83 & 107 & 94 & 102 \\
\hline Bicarbonate (mg/l) & 44 & 40 & 31 & 70 & 120 & 60 & 48 & 10 \\
\hline Calcium (mg/l) & 112 & 94 & 119 & 102 & 184 & 138 & 193 & 171 \\
\hline Total Hardness (mg/l) & 74 & 70 & 72 & 71 & 170 & 130 & 141 & 163 \\
\hline Magnessium (mg/l) & 5 & 3 & 5 & 5 & 10 & 5 & 8 & 6 \\
\hline Sodium (mg/l) & 4.1 & 4 & 4 & 4 & 4.2 & 4.7 & 4.5 & 4 \\
\hline Potassium (mg/l) & 10 & 8 & 10 & 8 & 12 & 10 & 14 & 10 \\
\hline Sulphate (mg/l) & 0.1 & 0.1 & 0.1 & 0.1 & 0.2 & 0.2 & 0.4 & 0.2 \\
\hline Nitrate (mg/l) & 0.6 & 0.38 & 0.25 & 0.3 & 0.6 & 0.4 & 0.3 & 0.4 \\
\hline Iron (mg/l) & 0 & 0 & 0 & 0 & 0 & 0 & 0 & 0.2 \\
\hline Copper (mg/l) & 1 & 1 & 0.3 & 2 & 3 & 3 & 1 & 5 \\
\hline Phosphate Chloride (mg/l) & 0 & 0 & 0 & 0 & 0 & 0 & 0 & 0 \\
\hline Heterophic Count (cfu/100 ml) & 320 & 300 & 301 & 310 & 410 & 360 & 320 & 400 \\
\hline Total Coliform (cfu/100 ml) & 100 & 91 & 90 & 70 & 120 & 102 & 98 & 71 \\
\hline
\end{tabular}




\begin{tabular}{cccc}
\hline Feacal Coliform cfu/100 ml & 6 & 4 & 10 \\
result showed that fifteen out of twenty seven parameters
\end{tabular}
measured before the rainfall in all the ponds fall within WHO permissible limit and they include $\mathrm{pH}$, salinity, carbonate, bicarbonate, calcium, total hardness, magnesium, sodium, potassium, sulphate, nitrate, manganese, copper, phosphate chloride and residual chlorine. These parameters also fall within the WHO standards after the rain event except for nitrate in all the ponds and $\mathrm{pH}$ in ponds 1, 2 and 3. However, it was generally observed that the values of the parameters increased after the rain obviously because they constitute the pollutant load which were washed off by the flood while passing through various impurities such as industrial and commercial solvents, metals and salts, radioactive materials, pesticides, decaying materials and other contaminants
10

which end up in these ponds. The computation of the average of the values of those parameters in the four ponds during and after the rain (Table 2) confirms that. Those parameters which were higher even before the rain were probably so because of their accumulation over the years. At 95\% confidence level, the F critical (2.05963) was greater than the F calculated (0.383372), hence we accept the null hypothesis which is consistent with the observation earlier made that the flood has significantly affected the water quality of these ponds (Table 3).

\section{Conclusion and Recommendation}

The study showed that about $58 \%$ of the twenty-seven parameters analyzed exceeded the WHO standard after

Table 2. Average values for all ponds before and after rain.

\begin{tabular}{|c|c|c|c|}
\hline Parameters & Average before Rainfall & WHO & Average after Rainfall \\
\hline \multicolumn{4}{|l|}{ Appearance } \\
\hline Temperature $\left({ }^{\circ} \mathrm{C}\right)$ & 25.5 & 25 & 26 \\
\hline Colour (Pt-co) & 116.25 & 50 & 190 \\
\hline Turbidity (FAU) & 37.5 & 25 & 60 \\
\hline \multicolumn{4}{|l|}{ Odour } \\
\hline $\mathrm{PH}$ & 7.75 & $6.5-8.5$ & 8.375 \\
\hline Conductivity $(\mu \mathrm{ohms} / \mathrm{cm})$ & 612.5 & 500 & 1130 \\
\hline TDS (mg/l) & 557.75 & 500 & 940 \\
\hline BOD (mg/l) & 2.5 & 2 & 5 \\
\hline Carbonate (mg/l) & Nil & 500 & 10 \\
\hline Salinity (mg/l) & 46.75 & 500 & 60 \\
\hline Bicarbonate (mg/l) & 31 & 500 & 102 \\
\hline Calcium (mg/l) & 46.25 & 200 & 59.5 \\
\hline Total Hardness (mg/l) & 106.75 & 500 & 171 \\
\hline Magnessium (mg/l) & 71.75 & 250 & 163 \\
\hline Sodium (mg/l) & 4.5 & 200 & 6 \\
\hline Potassium (mg/l) & 4.025 & 250 & 4.35 \\
\hline Sulphate (mg/l) & 9 & 400 & 10 \\
\hline Nitrate (mg/l) & 0.1 & 1 & 0.4 \\
\hline Iron (mg/l) & 0.3825 & 0.3 & 0.4 \\
\hline Manganese (mg/l) & 0 & 0.1 & 0.2 \\
\hline Copper (mg/l) & 0.1 & 1 & 0.4 \\
\hline Phosphate Chloride (mg/l) & 1.075 & 10 & 5 \\
\hline Residual Choride (mg/l) & 0 & 0.5 & 0 \\
\hline Heterotrophic Count (cfu/100 ml) & 307.75 & 300 & 400 \\
\hline Total Coliform (cfu/100 ml) & 87.75 & 10 & 71 \\
\hline
\end{tabular}




\begin{tabular}{|c|c|c|c|c|c|c|}
\hline \multicolumn{2}{|c|}{ Feacal Coliorm (cfu/100 ml) } & \multicolumn{2}{|l|}{6} & \multicolumn{2}{|l|}{0} & 10.75 \\
\hline \multicolumn{7}{|c|}{ Table 3. ANOVA statistical analysis. } \\
\hline \multicolumn{7}{|l|}{ ANOVA } \\
\hline Source of Variation & SS & $d f$ & MS & $F$ & P-value & F crit \\
\hline Between Groups & 147558.626 & 7 & 21079.8 & 0.383372 & 0.911281 & 2.059637 \\
\hline Within Groups & 10117292 & 184 & 54985.28 & & & \\
\hline Total & 10264850.63 & 191 & & & & \\
\hline
\end{tabular}

the rain event. All bacteriological parameters examined exceeded the WHO standard both before and after the rain. This implies that people that squeeze bitter leaf, process cassava, wash meats and utilize these ponds for other things most likely expose humans to all sorts of health hazards. The increment in the values of the analyzed parameters after the rain and the statistical analysis shows that the flood impacts significantly on the ponds and the pollutant load will continue to increase ad infinitum. It is recommended that people should be mindful of what they use these ponds for. Government should enlighten people to desist from disposing their wastes into the drains as this will reduce the level of pollution.

\section{REFERENCES}

[1] S. Tunstall, S. Tapseli, C. Green, P. Floyd and C. George, "The Health Effects of Flooding: Social Research Results from England and Wales,” Journal of Water and Health, Vol. 4, No. 3, 2006, pp. 365-380.

[2] E. E. Ezenwaji and A. C. Okoye, “The Relative Contributions of Climatic Elements and Environmental Factors to Urban Flooding in Awka Urban Area," 52' Annual Conference of the Association of Nigerian Geographers, Sokoto, 2007, pp. 168-170.

[3] R. A. Offiong and A. D. Eni, "Urban Floods: An Appraisal of the Effect of Flooding on Urban Infrastructure in Calabar Metropolis, Cross River State Nigeria,” In: A. B. Mamman, et al., Eds., Urbanization, Resource Exploitation and Environmental Stability in Nigeria, Joyuce Publishers, Kaduna, 2007, pp. 280-291.

[4] I. Abaje and P. N. Giwa, "Urban Flooding and Environmental Safety: A Case Study of Kafanchan Town in Kaduna State,” In: A. Mamman, et al., Eds., Urbanization,
Resource Exploitation and Environmental Stability in Nigeria, Joyce Publishers, Kaduna, 2008, pp. 32-40.

[5] L. N. Muoghalu and A. Okonkvvo, "Effects of Urban flooding in Awka Capital of Anambra State, Nigeria,” Environmental Review, Vol. 2, No. 2, 1998, pp. 112-121.

[6] A. J. Sadat, "Rainfall Intensity and Duration as Two Factors of Flooding in Humid Tropics," Journal of Atmospheric Science, Vol. 6, No. 1, 2009, pp. 10-16.

[7] B. E. Eze, “Topography and Urban Expansion as Twin Factors of Street Flooding in Calabar Municipality, Cross River State,” In: F. E. Bisong, Ed., Geography and the Millennium Development Goals, Translating Vision to Reality in Nigeria, Proceedings of the 50th Conference of Association of Nigeria Geographers (ANG), Index Book Publishers Ltd., Calabar, 2009, pp. 185-193.

[8] R. O. Sule, "Environmental Consequences of Rapid Urbanization in Countries of the Developing World," Thumb prints International Company, Calabar, 2004.

[9] B. L. Slamaker, "Urban Developments and Problems of Flooding in Nairobi,” Journal of Urban Affairs, Vol. 6, No. 1, 2000, pp. 1110-1119.

[10] A. G. Onokerhoraye, "Benin: An African City in Transition,” The Benin Social Sciences Series for Africa, 1995.

[11] National Population Commission (NPC), "Population figures for Nigeria,” Government print, Abuja, 2006.

[12] T. Mamta, "Quality Assessment of Water and Waste Water,” Lewis Publishers, London, 1999.

[13] Anon, "Hach Dr/890 Colorimeter Procedures Manual," Hach Company, Loveland, Colorado, 1997.

[14] APHA, "Standard Methods for the Examination of Water and Waste Water," 17th Edition, American Public Health Association, Washington DC, 1991.

[15] Anon, "Water Microbiology Laboratory and Field Procedures,” Millipore Corporation, Bedford, 2000. 